Article

\title{
On the Colonial Past of Anthropology: Teaching Race and Coloniality in the Global South
}

\author{
Maria Andrea dos Santos Soares \\ Social Sciences, UNILAB, São Francisco do Conde 43900-000, Brazil; mandreasantos@unilab.edu.br
}

Received: 22 November 2018; Accepted: 28 April 2019; Published: 8 May 2019

check for updates

\begin{abstract}
This article addresses some of the discussions taking place at the Social Sciences program of the Afro-Brazilian International University for Lusophone Integration (UNILAB), such as the coloniality of knowledge, racial hierarchies, and anthropology's complicity in colonialism. The article reviews current literature and draws on ethnographic fieldwork for two main purposes: First, to analyze how Afro-Brazilians, and Afro-Brazilian culture have been depicted and used in the process of national formation. Second, to examine the role that social and anthropological analysis played by dismissing "race" and "racism" as a structuring feature of Brazilian society. I propose that the ethics of an anthropological praxis aiming to create the necessary conditions for a different kind of knowledge to emerge, would be critically reflective about its own process of knowledge production, and aware as well, of voices and locations where this knowledge is being produced. The process of decolonization relies on epistemological choices made in the field, at the institutional level within the departments and programs, and in classrooms.
\end{abstract}

Keywords: anthropology; colonization; Brazil; race; UNILAB; decolonization; Global South

\section{Introduction}

It is possible to say that I have the job of my dreams. As a black Brazilian anthropologist and graduate of an African Diaspora Studies Graduate program at a reputable U.S. University, I have the privilege of teaching in a Brazilian University that was planned as a bridge between Brazil and the African continent. Created in 2010, UNILAB-Afro-Brazilian International University for Lusophone Integration is a public federal university whose four campi are located in two Brazilian states: three campuses are located in the state of Ceará (where the Dean's Office is located), and one campus, "Malês" Campus, is in the municipality of São Francisco do Conde, Bahia state. Presently, UNILAB has 4172 enrolled students (counting all its campi) from the countries belonging to the Lusophone Community. As a historical outcome of the struggles of the black social movements, this institution's project emerged from the initiative of the administration of 2005 to 2012 focusing on the politics of bringing higher education institutions to small cities and rural areas across Brazil. At the same time, UNILAB's project aims to increase international cooperation among Brazil and the Portuguese speaking African Countries at the level of economics, science, technology, and education.

The need for new epistemologies, decolonial knowledge, and struggle against the different aspects of racism, which is still deeply rooted in the nation (due to history and the experience of slavery), turns the project carried out by UNILAB into a historical landmark for affirmative action in Brazilian education. The discussions, courses designs, and syllabi at UNILAB focus on goals and themes, such as the decolonization of educational practices; "race" as a category in Brazilian and in African contexts, black feminisms; the politics of fighting racism; and the implementation of Federal Laws 10.639-03 and 11.645-08 (which, respectively, mandate the teaching of African history, and of Afro-Brazilian and indigenous culture at all levels of formation). Thus, while teaching at this particular institution 
(which, we need to say is also a longtime dream for many black intellectuals in Brazilian academy), a constant critique of the canon and of our own practices and methodologies is necessary.

In this article, I seek to reflect upon anthropological theory and practice while simultaneously thinking through its importance as a socially relevant field of knowledge and knowledge production. The article starts by pinpointing how race, racial mixture, and Afro-Brazilian culture was, and continues to be, deployed in the context of the Brazilian nation. Hopefully, this will help us to grasp the intricacies of the "racial problem" in Brazil, and how the subject of race/racism was, or was not, addressed by Brazilian social scientists. Following an analysis of how "race", "racial mixture", miscegenation, Afro-Brazilian culture have been deployed by both state actors and social movements, I will discuss this historical trajectory in relation to UNILAB - an institution whose very founding was a result of progressive socio-political mobilization against racial inequality-and will advance a position regarding the anthropological practices and its canon, as well as the implications for anthropologists' positionalities according to race, gender, and region (Global South) of origin and of knowledge production.

\section{A Black University and an Anthropological Canon}

Imagine yourself coming into a classroom on your first day at your new university. Imagine your happiness as an Afro-Brazilian woman seeing, for the first time in a Brazilian university, a majority of black students. Imagine yourself celebrating the exchange with African brothers and sisters. Now you start your class. What is the topic? Introduction to Anthropology, "Here is Mr. Morgan, he classified human races as savages, barbarians, and civilized. Guess where you were in his estimation?; "Oh, and here we have the man who systematized the ethnographic method, Mr. Malinowski-who, in the private diary he kept during the fieldwork among the Trobriand people referred to the Tobriand girls as "little animals""1; "Do not miss this one, we need to read Mr. Pritchard-who could not understand why the Nuer were so mean to him!"2 Here is Mr. Radcliff-Brown-ignore the fact that in his analysis, he refused to take into consideration the historical changes brought on by colonialism. ${ }^{3}$ Here is Mr. Griaulle, (we shall remember him every time we see African artifacts in any random European museum $)^{4}$; The examples of abuses, misuses, and racism in the anthropological field could go on (maybe forever, I am afraid).

UNILAB - an institution of higher education whose main goal is to promote academic exchange with Portuguese speaking African countries, has students seated in the classroom, who come from different places, countries, regions, and ethnic backgrounds. However, for most of them, one thing is clear: They/we are the descendants of those who were once the object of demeaning, racialized schemas of categorization. Yes, many schools of thought have criticized the role that anthropology played in colonization-poststructuralism, writing culture, writing against culture, postcolonial theory. We can easily say that nearly every anthropologist is familiar with the critics of the colonial aspects of the work of renowned anthropologists, such as Evans Pritchard and Bronislaw Malinowski, and how much of the research conducted by those who are now part of the anthropological canon has collaborated with the colonial project, or, at the very least, were complicit in its politics. But consider the following: What

1 "At the 5 went to Kaulaka. A pretty, finely built girl walked ahead of me. I watched the muscles of her back, her figure, her legs, and the beauty of the body so hidden to us, whites, fascinated me. Probably, even with my own wife I 'll never have the opportunity to observe the play of back muscles for as long as with this little animal. At moments I was sorry I was not a savage and could not possess this pretty girl." In: Malinowsky, Bronislaw. 1967. A Diary in the Strict Sense of the term. p. 255.

2 Evans Pritchard conducted fieldwork among the Nuer, a social group in the Sudan. By the time of his work, the Nuer were under the British Colonial rule, but Pritchard ignored the presence of the colonial powers and the changes it brought to this society.

3 See Assad, Talal "Introduction" In Anthropology and the Colonial Enconteur. 1995.

4 Marcel Griaulle was part of the expedition Dakar to Djbouti, which crossed the African Continent between 1928 and 1933. Along this expedition many artifacts and art pieces were taken and brought to France. See Michel Leiris Africa Fantôme, Seagull Books, 2017; also Andrew Apter "Griaule's Legacy: rethinking "la parole claire" in Dogon studies" in Cahiers d’Études Africaines, vol. 45 (177), 2005. pp. 95-130. 
if the anthropologist, as well as her or his students, does not belong, in terms of race, class, gender, and national or regional origins to the groups usually entitled to produce discourses, representations, and scientific knowledge about the others? What if these "others" are operating in the field to question, to critique, or even to dismantle the canon? What happens then to the versions of anthropology that we were taught?

By practicing anthropology while being part of certain groups-black, women, indigenous people-people like me, my colleagues, and my students operate within a discipline that has contributed to place ourselves as the "Other" of Western thought and actions, and this, by implication, means promoting a practice that seeks to change paradigms, to change epistemologies, and to change objectives, and investing in the social function of knowledge. By doing so, we establish an inquiry about anthropology's origins and applications. At the same time, we are invested both in anthropology's potential to understand human beings in society and in using this condition of "Otherness" as a tool for promoting change in the world. To produce alternate models and theoretical frameworks, it is necessary to engage in a critical review about not only the misuses of anthropological science and practice but also to be critical of the regimes of authority and regulation that determine either the hegemonic places of its production-Europe and the U.S.- as they determine the conditions of its production in the Global South. In what follows, I present a brief review on how the racial question evolved in Brazilian anthropology to grasp different approaches at different times and to point out the persistent essentialization and refusal to engage Afro-Brazilians as political and epistemological agents.

\section{The "Race" Problem in Brazil}

In Brazil-the biggest plantation system of the Americas and the last country to abolish slavery-there were rumors at the end of the nineteenth century that the country would never attain development and progress because, according to theorists of eugenics, no development would be possible in a country where the different "races" so intensely mixed among themselves. The problem of race mixing really annoyed politicians, social theorists, physicians, and psychiatrists. One such person is Nina Rodrigues-regarded as the first Brazilian anthropologist and ethnologist. To Rodrigues, the "mestizo" would represent the corruption of civilization, the biological proof of contamination that would undermine the nation. To him, ethnology should work to support sanitation policies, and control of the state over black populations (Pinho 2010).

But, some scholars soon started to see the bright side (irony here) of racial mixture. Arthur Ramos, Nina Rodrigues' disciple, soon abandoned the determinist perspective of his mentor, favoring a cultural anthropology approach. The problem is, by replacing race with culture, Ramos also emphasized the unfinished acculturation of the black communities into the modern (white, European) structures of society. Thus, the future of the nation would rely on the complete assimilation of the black population, a process that demands control by the state, and by the system of education (Rocha 2016). Arthur Ramos subsequently disputed the field of cultural anthropology with Gilberto Freyre and the substitution of the concept of race by culture. Freyre, who built his legitimacy by studying with Franz Boas, was invested in celebrating racial mixing. According to him (among other enthusiasts of mixing as specifically "whitening") the "Brazilian race"—-brewed in the mixture-was the future; a future where the best qualities of the Africans-inherited from the enslaved women breeding babies from their white owners-would be assimilated in the mostly white features of the new generations of Brazilians (Rocha 2016). By doing so, Freyre also reduced any racial problematic to the question of cultural difference (Pinho 2010).

During the Estado Novo (the New State), the populist regime inaugurated during president Getúlio Vargas's administration from 1937 to 1945, there was a movement towards the election of national symbols. This movement included the aggregation of cultural practices, such as capoeira, Candomblé, and samba, as expressions of the Brazilian spirit and nationalist devotion. The appreciation of practices, until then marginalized and often criminalized, indicates that the eugenic project, championed by politicians, intellectuals, and scientists, such as Nina Rodrigues, gave space to a new politics of 
assimilation. As a part of these new politics, the recollection of Africa, through its culture and folklore, supposedly honored African heritage, when in fact it was just a mimicry of the real existence of people of African descent in Brazil (Soares 2015; Hanchard 1999; Twine 1998; Skidmore 1990). In the same way, this memory of Africa also endorsed a mythical narrative of slavery, romanticized as a sad, but necessary, and generative episode of Brazilian history where the mistake of enslavement was overcome through miscegenation (Ferreira da Silva 2006; Munanga 1999).

If, on the one hand, it is safe to say that the religious and cultural aspects of black life in Brazil are considered an important (if not the most important) source of Afro-Brazilian identity and resilience for a large number of black activists and intellectuals, on the other hand, it is also clear that these realms of black existence were often criminalized and persecuted by the state's institutions. The medical and psychiatric discourse of Nina Rodrigues regarding the religious practices of Candomble is one example, as are the laws prohibiting the public practice of capoeira and the samba meetings during the 1920s (Rodrigues 2006; Assunção 2005). However, these signs of an "African heritage" were later chosen as national symbols (Smith 2016; Nascimento 2007; Hanchard 1999; Nascimento and Lopes 1987).

Regarding anthropological practice in Brazil, it could be said that unlike the sociological approaches, this followed the logics of nationalist discourses of assimilation. Thus, foreign scholars during the 1930s to the 1970s focused, in general, on the cultural aspects of black life. Ethnographers from the United States, such as Landes (1994), and Melville Herskovits (in Guimarães 2008); and from France as Pierre Verger (in Pinho 2010), and Bastide (1971) directed their attention and ethnographic description towards Afro-Brazilian religion from the 1940s to the 1980s. From the 1970s to the 1980s, Brazilian anthropologists took a similar approach by also focusing on the study of "black culture", centering their analysis on the Afro-Brazilian religions (Candomblé and Umbanda) or in the expressive practices related to the Afro-Brazilians, as we see in Hermano Vianna works on samba music and dance (Vianna 2012) and on funk music and parties (Vianna 1997).

Urban anthropology studies gained force in Brazil in the 1980s. During this period a whole generation of prominent Brazilian anthropologists started to look to the dynamics of complex, urban societies, producing several studies on urban violence, urban youth, and subcultures. Even so, the focus on social class as the structuring force behind inequalities and the subjection to violence often relegated the question of racial formations in Brazil, and racial inequality to a second or third plane. As Otávio Velho observes, many Brazilian anthropologists look for the "other", for the "exotic" within the nation (Velho 2008). The result was that black people and indigenous people, even if they were intellectuals, were not taken as equals in a scholarly dialogue; they were not even seen as social agents in the process of national formation.

On the one hand, renowned Brazilian anthropologists chose to deal with Afro-Brazilians through the lens of culture, and cultural difference or assimilation, on the other hand, important anthropological analysis focusing on racial formations in Brazilian society, and racism as the main structuring force was done by foreign scholars, such as Harris (1964), Twine (1998), Pravaz (2003), and Goldstein (2013). These are examples of ethnographic research done in Brazil during the 1970s through the early 2000s that call attention to the fallacy of the "racial democracy" narrative, to the blatant racism within Brazilian society, to the subtleties of racial denominations, and to the imprecision of "race" in Brazilian (and Latin American contexts), a categorization that was less related to familial origin and more related to phenotype. From the late 1990s to the early 2000s, a new generation of Brazilian anthropologists, or foreign anthropologists working in Brazilian universities, published relevant works regarding racial questions in Brazil. Some examples are Sansone (1998), Munanga (1999), Pinho (1999), Schwarcz (1993), and Carvallho (2001). The publication of Raça: Novas Perspectivas Antropológicas (Race: New Perspectives in Anthropology) organized by Livio Sansone and Osmundo Pinho appeared in 2008 and still represents a groundbreaker in the field. The strength of the work is due to the wide range of topics and subjects, the diversity of voices in terms of gender, race, and the subfield of study, and the seriousness of its methodological and analytical frame (Sansone and Pinho 2008). 
Parallel to the emergent attention to racial matters in certain circles of anthropological research, the period between 1988 and 2003 brought important changes regarding the racial question in Brazil: The Federal Constitution of 1988 proposed regulation of quilombo or maroon lands, and in 1989 the Caó Law proposing punishment for racial discrimination was created. In 2001, the Brazilian Black Social Movement participated in the World Conference against Racism in Durban. The SEPPIR (Ministry of Racial Equality Promotion) was also created in 2003 (fused with the Human Rights Secretariat and with the Politics for Women Secretariat in 2015). The adoption of affirmative action policies in higher education started in 2005, and in 2012 affirmative action was ruled legal and made mandatory in all public institutions of higher learning. All those events occurred through national and international mobilization of social forces, among them the Unified Black movement and its activists, such as the scholar, artist, and politician Abdias Nascimento, the first proponent of affirmative action policies for Afro-Brazilians in the early 1980s. Many of the Black Social Movement activists were also active in academia, as, for example, historicist Beatriz Nascimento, who in the early 1980 called attention to the quilombos communities, and Lélia Gonzalez, anthropologist, politician, and women's rights activist who was interested in the study of gender and its intersection with race, as well as in discussions on the mental health of black activists.

Regarding the debates on the adoption of affirmative action policies during the years of 2003 to 2007, Brazilian anthropologists were divided between the ones who thought it was a necessary measure and the ones who thought it was not a good policy. Interestingly enough, the position adopted by some anthropologists working with Afro-Brazilian culture, religion, or racial inequality, was to oppose affirmative action laws, insisting either on the idea that mirroring the U.S. policies would not help the Brazilian case, or on the idea that adopting ethnic or racial criteria for higher education enrollment would create a "racial divide" in Brazil.

\section{Anthropologists and "Others"}

A sincere question needs to be introduced here. Once we know the hard truths about anthropology's colonial past, once we know how the field so often overlooks political questions regarding blackness and racial relations in Brazil (as in other places); how can women, black people, Africans, indigenous groups, the "Others" of the Western philosophy, consider anthropology as valuable knowledge? What are its aims?

This is a discussion gaining strength among anthropologists, especially among those who by criteria of race, gender, national origin were somehow cast as outsiders by the main canon. Starting in the 1980s, scholars have been pointing out both issues in different ways; the white male ethnocentric gaze held as "universal knowledge" (scientific, neutral, objective, and also validated for equally neutral and objective scientific pairs), and the hegemonic ways and locus of knowledge production and dissemination. Some critics advance claims for a "native anthropology," aiming at replacing loci of power and hegemonic voices (white, male, heterosexual, Western) in the anthropological discourse by speaking from different places as the other, as does Lila Abu-Lughod, for example, when she claims the status of halfies (Abu-Lughod 1991). However, as Ayse Caglar analyzed, the very notion of halfies is based in the original separation between "Us" and "Them" that always was part of the canon (Caglar 1997). Escobar and Restrepo also pointed to what they considered to be a limitation in the claim for a native anthropology because, although it attempts to speak as an outsider voice, it does not represent or propose any epistemological change (2005). Thus, even during its moments of self-criticism, anthropology remained located in the North (U.S.) as the center of knowledge production and dissemination, as it continued to reproduce the same hegemonic methodologies and epistemologies, whereas anthropologists in the South would continue replicating the center, validating its works, scholars, findings, and even critics.

The decolonial turn promoted by scholars, such as Boaventura Santos, Arturo Escobar, Anibal Quijano, Walter Mignolo, and Enrique Dussel argues for an epistemological rupture where such concepts as the coloniality of power and the coloniality of knowledge would help us to both understand 
and dismantle structures of power and symbolic schemas of dominance while centering the Global South, and more specifically Latin America, as the source of new (or recovered) epistemologies. Still, the predominance of white Latin American and Portuguese men producing their work from Europe (Boaventura Santos) or from the US (Escobar), leaves some room to ask about other voices that are still missing in this process of decolonizing anthropologies in the Global South. What that means is that it is necessary to ask about the value of black and indigenous people, black and indigenous women practicing anthropology either in the Global South, as the ones practicing the discipline at the peripheries of departments and programs in the North. In both cases, these other anthropologists are doing work with less funding, fewer publishing opportunities, less training, and less validation.

In her seminal work Decolonizing Anthropology, African-American scholar Faye Harrison (never translated into Portuguese in Brazil) states the need for committing ourselves to rethink practices, and to rework the discipline by taking the worlds, the epistemologies of subaltern groups seriously (Harrison et al. 1991). The need for recapturing a tradition of black anthropologists in the U.S. appears in her work as a way to shed light on academic trajectories that would be otherwise erased from the discipline's history. In a recent interview, Harrison reassures us of her commitment to considering also the necessity of validating the anthropologies being produced by black, brown, indigenous people in the so-called Global South (Harrison et al. 2016), that is, not only "where" a peripheral anthropological knowledge is being produced but "who" is producing it. Thinking of Brazilian anthropology, it could be said that from the perspective of hegemonic places, such as the American Departments of Anthropology, the work being done in the tropics is peripheral, meaning either that it is less important, or visible, or meaning that finally, anthropology is bringing in other voices. However, the Global South has its own hierarchies of race, gender, and validity of knowledge. As indicated earlier, Brazilian anthropology was predominantly non-black, non-indigenous, and, at least until recently, not welcoming towards approaches on race that escape the realm of culture to touch on more political aspects of racial relations in Brazil.

As a graduate of the U.S., center of power, but from a program oriented to the study of the African Diaspora and to Activist Anthropology-the former very often mistaken as the study of black "culture", and the latter being a subfield that is not even known in Brazil-I can think of my own position in the Brazilian academy as an intertwined spiral of both privilege and disadvantage. First, both programs, although operating in a very important institution, generally have access to less funding, less space and power of decision despite their importance as attractive programs for graduate students seeking degrees in Social Sciences with some level of social commitment. Second, the Brazilian academy has difficulty in accepting alternate canons, and interdisciplinary studies (or scholars' interdisciplinary training). This affects the possibilities of research design, which in turn affects the opportunities for funding and publication and even for employment. Finally, the political moment Brazil is going through poses serious threats to the future of critical thought and reflective practice in the Humanities as a whole. Even more delicate is the situation of those universities created during president Lula's term, as is the case of UNILAB, created to promote exchange with the African continent, a project that apparently is of no interest to the present government.

\section{Same and Other: Experiences of a "Native" Ethnographer}

After reflecting on almost a decade of fieldwork, I can appreciate how cultural expressions and art forms utilized by African descendants, have been deployed in the Nation's narrative of racial democracy or, more recently, "neoliberal multiculturalism" (Hale 2005).

The celebration of a "traditional" African heritage is often times emphasized in Brazilian culture: cultural practices, such as samba music, Candomblé, carnival, and capoeira. On the one hand, these practices are key elements of resistance and the symbolic life of black communities, many times adopted by activists to assure dignity and collective mobilization (Hanchard 1999; Nascimento and Lopes 1987). On the other hand, this celebration of African heritage is frequently used in Brazil to demonstrate the plausibility of the "racial democracy" narrative (Soares 2015; Freyre 2002; Ribeiro 1995). This 
perspective, which can be related to a broader ideology of mestizaje, spread throughout Latin America which celebrates the mixed cultural (and racial) heritage as one of the pillars of a national foundation. The rhetoric of mestizaje offers an alternate discourse to the racial purity ideology in the U.S. and to the eugenicists' views of Brazilian politicians, medical doctors, and sociologists from the early twentieth century. Mestizaje suggests the foundation of a new and superior race whose creation is dictated by the assimilation of black and indigenous elements into the white dominant features of the population (Smith 2016; Martinez 1998; Graham 1992; Skidmore 1990).

My ethnographic experiences are based on participation and observation, placing particular significance on the Afro-Brazilian artistic collectives, and college groups, on the cooperation tactics among black women and their ways of organizing or resisting racism, and on the dialogues and/or retreats between Black Social Movement actors and the State. I conducted fieldwork research in three Brazilian states: Bahia, Rio Grande do Sul, and Rio de Janeiro, and I will bring here aspects from the fieldwork experiences to outline some reflections regarding my own positionality and role in the field.

The city of Rio de Janeiro, where I conducted extensive fieldwork among a collective of black artists and cultural producers, is well known for its depictions of Afro-Brazilian culture, such as the carnival parade, samba music and dance, capoeira, Afro-Brazilian religion, and cuisine. However, according to artists and producers who are my research collaborators, the ones who have historically profited from the selling of black cultural production are the white entrepreneurs in charge of show houses, theatre houses and companies, the recording industry, tourist agencies, press, and other such ventures. The collective of black artists and cultural producers organized themselves in a mobilization called Akoben-a word that comes from the Adinkra symbology (from the Akan people in west Africa), meaning "Horn of War". Among their demands, was the adoption of affirmative action criteria in the funding opportunities designed to promote culture and art. Their actions included a video named "Cultural Eugenics" (circulated on YouTube) denouncing the committees' all-white composition and the frequent dismissal of black producers' proposals in favor of art proposals presented by white producers, a lawsuit against a state bank due to a suspicious action in a funding decision, and a campaign encouraging black artists and producers to apply for state funding. As a result of Akoben's mobilization, a funding opportunity exclusively designed for black artists and cultural producers was created in November 2012 by Marta Suplicy, Minister of Culture at that time. In addition, the main leader of the mobilization, theater actor and director Hilton Cobra was invited to direct the Palmares Foundation-a state institution related to the Ministry of Culture whose main goal is to preserve and to promote Afro-Brazilian heritage and culture.

A few things learned from this fieldwork experience that can be pinpointed here are that: (A) my position as a black woman, coming from mainly white southern region of Brazil, but studying in a U.S. institution, positioned me in an awkward position. At the same time, I have some credentials to conduct research (which does not mean all participants would trust any researcher); in fact, they were refractory at the beginning. My blackness worked as a positive factor to establish trust in terms of making the participants feel free to talk about racism and their experiences, in the same way that my gender guarantees a greater exchange with the women. My interdisciplinary formation (background in theater and art education) made room for intense conversation and even future (never accomplished) artistic projects. At the same time, notwithstanding the fact that I was in so many aspects similar to them, my peripheral origin (the South) often made some of the participants question my blackness, or my understandings about black activism and art. (B) The relationship established with the numerous members of the collective varied immensely. With some of them, the conversations remained in the form of interviews, with others I maintained an intense dialogue, even after the fieldwork was done. These intense dialogues also varied according to gender; with some of the men, especially those pursuing academic careers, the conversations were more in terms of academic debates and exchange, as well as the challenges of black social movements in Brazil and in the world. With the women, the aspect of the black struggle against racism was also central, but with them, I frequently socialized at parties, and our conversation often led to subjective matters, such as loneliness, the family, 
health issues, and romantic life. The intense dialogue between anthropology, theater, and black social activism often blurred the lines between a black ethnographer and black Brazilian women eager to contribute to black activism. (C) The ways in which the work of the ethnographers can be useful for the social groups became apparent in at least two moments: The first, when members of the collective asked me to write the minutes of the meetings since I would be taking notes anyways. The second moment was during the organization of research data when I became aware of the need to present tables showing the distribution of the main federal funding opportunities for the arts during the years of fieldwork (2012 and 2013). These tables showed unequivocally that the vast majority of artistic projects chosen were headed by white producers, even when they were related to black themes. In this way, an idea that I discussed with some of the collective was to keep updating the tables, even expand them to state and city funding to collect enough material to present reports which could help black producers to prove to the State they have been constantly pushed aside. (D) My decision to live in Rio de Janeiro - the working class neighborhood of Honório Gurgel in the North area-determined a level of understanding about the city dynamics that would not be possible if I had chosen to stay in the central area (where many of the Akoben participants live, and where all the meetings happened). Riding the public transportation so many times per week, so many hours, meeting so many unknown people every day, traversing territories which I have heard about on TV so many times (either in the romantic soap operas, or in the police reports), led me to establish three levels of fieldwork: the main level, the tangent level, and the transversal level. The main level includes the Akoben mobilization itself, its goals, ways of organizing and acting, the meetings, the artistic works presented by the members, and the interviews. The tangent level was related to black cultural life in the city of Rio de Janeiro. For example, by living nearby the Madureira neighborhood—a big commercial center, and also a very traditional place for black culture (it is considered one of the birthplaces of samba music) - I had the opportunity to attend different events, such as samba schools rehearsals and shows. My collaborators also invited me to numerous other socializing moments, including a wedding, birthdays, and a requiem mass. All those events and gatherings gave me a better perception of people's lives, ways of creating social bonds, and the dynamics of black spatiality in Rio. The transversal level relates to all the circumstances of being a black single mother living in the North working-class area of Rio de Janeiro: to all the hardships about the weather, the conditions of public transportation, the fear of violence, the sounds of gunfire, the friendships I made, the elementary school conditions, and the dialogues (and collaboration) with teachers. In a word, the third level was everything that affected me while giving me the full materiality of an existence in that city. This choice to approach the fieldwork as tree levels of ethnographic experience was made as a way, or a cognitive cartography, to create in writing the same density I experienced in the field.

Through the fieldwork experiences, I seek to discuss how the activism practiced by groups, collectives of artists, and college students bring questions of cultural appropriation and of material and symbolic alienation as effects of racism to the forefront of public debate. At the same time, these collectives, these ensembles, these artistic practices in theater, dance, literature, music, as well as these confrontations against racially hierarchical institutions (colleges, state departments, ministries, and so on) create grounds for a struggle collectively built and based on the recognition of racial inequalities. Such aesthetic and political processes resist material and symbolic forms of racial subjugation while simultaneously creating a space for exchange and learning, for the establishment of professional networks, and for political action. But the fieldwork also revealed the challenges and limitations of black social movements in Brazil, the ways the state coopts black activists-as in the case of the Akoben leader who was invited to manage a state institution. By accepting this position, he could not continue to organize the mobilization, much less pursue the lawsuit against the state bank. The alliances with political parties play a great role in terms of disaggregating black activists, as well as the regional disputes in terms of leadership in the national representation of this social movement. The conflicts between the desire for a more radical political practice and the usual tactics of negotiating with the 
state, as well as the attempts to create exclusively black spaces and the reality of professional, political or familial alliances with white partners also constitute sources of political and personal conflict.

The persistence of the rhetoric of mestizaje, allied with the state economy of tourism, turns blackness and the eroticized narrative of mixing into a profitable business (Clarke and Thomas 2006; Pravaz 2003; Alexander 1994). Expressive Afro-Brazilian culture constitutes a profitable commodity in the tourism-driven city of Rio de Janeiro at the expense of the well-being of black and poor citizens (Soares 2016; Amar 2016). This is not a phenomenon restricted to Brazil; in other places of the African Diaspora, similar phenomena occur. Countries, such as Jamaica and Cuba, are just two of these examples where blackness, aligned with the tropical climate, the landscape, and sex becomes the dream of a lost paradise/plantation to many tourists (Kempadoo 1999; Kinkaid 1988). Unlikely other Brazilian regions where the presence of black communities and their expressive practices is denied, rendered invisible and silenced - such as the southern Brazilian states (from where I came from) - the southeast (Rio de Janeiro and Bahia specially) cannibalizes African descendants' history, territories (through gentrification), and expressive practices. Thus, whereas in the southeast, black artists and cultural producers are fighting to have autonomy over their own productions, which are largely displayed for touristic consumption, the fieldwork carried out in Rio Grande do Sul state among black women and their practices of resistance through cultural and religious expressions, demonstrates that African descendants there need to prove their own existence along the social formation of this region that is frequently imagined as a totally white space.

\section{Closing Remarks}

When my first semester at the UNILAB was about to end, I heard one of the male students from Guine-Bissau saying to his coleague "I never thought I would like anthropology". Later on, I learned that five of them wanted to continue studying anthropology in their graduate school. I remember smiling in response. Did I convince them that anthropology had its bad guys, but you know...there are still beautiful things to learn about "human nature", social groups", "culture", "minorities", "identity"? Maybe this is not the case. Maybe we all just realized that we need to engage, we need to bring our voices, experiences and endogenous knowledges to question exogenous discourses, exogenous categorizations, and ethnocentric epistemologies. That is the reason why many of my students start to challenge previous studies, conclusions, and categories (tribe, ethnic groups, horizontal societies, and so on ... ) relating to their own societies. Bringing in another classroom example, I remember one of my students starting his essay on familial structure among the manjacos in Guiné-Bissau with the following sentence: "My last father passed away this year.". I remember frowning a little bit after reading this sentence, and then my voice repeating it followed by the weird feeling that something was out of my reach of understanding. A little later, I could start to grasp the deeper meaning of this declaration. The sentence disrupts the understandings about both models; the model of family within the Western structures of kinship, and the model of writing about family in anthropology. So, who is talking about family? An anthropologist, or a manjaco young man who has lost the last of his paternal uncles recently? Both. "Both" becomes one single promising young academic who dares to refuse the hegemonic scientific canon to describe African structures of kinship. This anecdote can teach us something about world narratives, world epistemologies, and, of course about world anthropologies (Restrepo and Escobar 2005). South African scholar Archie Mafeje proposes a "combative ontology", a rejection of exogenous canons, and the adoption of endogenous perspectives and epistemologies (Mafeje 2000). The student essay's anecdote could be a good example of what Mafeje means when he argues for the need to give validation to endogenous knowledge (2008). As a professor, very often I feel a need for catching up with African epistemologies, scholarly lineages, and African intellectuals, artists, writers, and anthropologists. We all need to because the continent is frequently rendered invisible as a locus of knowledge production, or of intellectual work. For centuries, Africa was the place where data was collected, where "natives" were classified, measured, and tested, a place full of raw material, but not a place producing scientific, or philosophical knowledge. To produce a critique of anthropological theory 
and practice while simultaneously thinking about the continuity of anthropology as a socially relevant science to a higher education project, such as the project presented by the UNILAB - an institution designed to establish cooperation programs with African Countries-requires the commitment to learning from African Intellectuals. More than that, it requires that we refuse to frame the "others" in terms of alterity (Adesina 2008) and embrace other ontological possibilities for people, for human groups and societies who explain their worlds in their own terms.

In this article, I have presented a brief review of the study of race, racial relations, and black culture in Brazilian anthropology, outlined a critique of the politics of power and knowledge distribution in the anthropological field, brought examples from ethnographic experiences, and my own teaching praxis at the UNILAB. Far from closing this discussion, or even coming to a definitive conclusion, what could be said for now is that by practicing anthropology while belonging to certain groups of people-black people, women, indigenous groups-people like me embrace a science that contributed to our creation as the "Other". Thus, we are on both sides of a mirror, we are the "natives", and we are "scientists". We are coming back to our communities and/or families, and we are engaged in the machinery of academia. Still, what type of anthropology we are proposing, how we narrate the history of our discipline and what choices exist in terms of research design, methodologies, and applications of our practice are serious matters we need to think about. Several authors have written about the meaning of anthropology, some say that it is to study other people and social groups and learn something about our own groups and societies. What I can say from my perspective is that the ethnographic encounters I have had, have allowed me to experience both collective learning as well as self-making.

Funding: This research received no external funding.

Conflicts of Interest: The author declares no conflict of interest.

\section{References}

Abu-Lughod, Lila. 1991. Writing against culture. In Recapturing Anthropology: Working in the Present. Edited by Richard Fox. Santa Fé: School of American Research Press, pp. 137-62.

Adesina, Jimi O. 2008. Archie Mafeje and the Pursuit of Endogeny: Against Alterity and Extroversion. Tunis: African Development, vol. XXXIII, pp. 133-52.

Alexander, M. Jacqui. 1994. Not just (any) body can be a citizen: The politics of law, sexuality and postcoloniality in Trinidad and Tobago and the Bahamas. Feminist Review 48: 5-23. [CrossRef]

Amar, Paul. 2016. Salvando o berço do samba no Rio de Janeiro: rebeliões do poder paralelo, infra nacionalismos urbanos e a política racial de securitização humana. In Antinegritude: O Impossível Sujeito Social na Formação Social Brasileira. Edited by Pinho Osmundo and Vargas João. Cruz das Almas and Belo Horizonte: UFRB and Fino Traço Editores, pp. 31-58.

Assunção, Matthias R. 2005. Capoeira: A History of an Afro-Brazilian Martial Art. London and New York: Routledge.

Bastide, Roger. 1971. As Religiões Africanas no Brasil. Contribuições a uma Sociologia das Interpenetrações das Civilizações. São Paulo: Biblioteca Pioneira das Ciências Sociais, vol. 2.

Caglar, Aye. 1997. Hyphanated identities and the limits of culture. In The Politics of Multiculturalism in the New Europe: Racism, Identity, and Community. Edited by Tariq Modood and Pnina Werbner. London and New York: Saint Martin Press and Zed Books, pp. 169-85.

Carvallho, José Jorge. 2001. As propostas de cotas para negros e o racism acadêmico no Brasil. Revista Sociedade e Cultura 4: 13-30.

Clarke, Kamari Maxine, and Deborah A. Thomas. 2006. Introduction. In Globalization and Race: Transformations in the Cultural Production of Blackness. E-Book. Durham: Duke University Press.

Ferreira da Silva, Denise. 2006. À Brasileira: Escrita de um desejo destrutivo. Revista de Estudos. Feministas 14: 61-83. [CrossRef]

Freyre, Gilberto. 2002. Casa Grande e Senzala. Edicao Critica. Madri: Allca XX.

Goldstein, Donna. 2013. Laughter out of Place: Race, Class, Violence, and Sexuality in a Rio shantytown. Berkeley: University of California Press.

Graham, Richard, ed. 1992. The Idea of Race in Latin America, 1870-1940. Austin: University of Texas Press. 
Guimarães, Antônio Sérgio. 2008. Africanism and racial democracy: The correspondence between Herskovits and Arthur Ramos (1935-1949). Estudios Interdisciplinarios de América Latina y el Caribe 19: 53-79.

Hale, Charles R. 2005. Neoliberal multiculturalism. PoLAR: Political and Legal Anthropology Review 28: 10-19. [CrossRef]

Hanchard, Michael. 1999. Orpheus and Power: The Movimento Negro of Rio de Janeiro and São Paulo, Brazil, 1945-1988. Princeton: Princeton University Press.

Harris, Marvin. 1964. Racial identity in Brazil. LusoBrazilian Review 1: 21-28.

Harrison, Faye V., Carole McGranahan, Kaifa Roland, and Bianca C. Williams. 1991. Decolonizing Anthropology: Moving Further Toward an Anthropology for Liberation. Edited by Faye V. Harrison. Arlington: American Anthropological Association.

Harrison, Faye V., Carole McGranahan, Kaifa Roland, and Bianca C. Williams. 2016. Decolonizing Anthropology: A conversation with Faye Harrison, Part I. Savage Minds-Notes and Queries in Anthropology, January 7.

Kempadoo, Kamala. 1999. Continuity and change: Five centuries of prostitution in the Caribbean. In Sun, Sex and Gold: Tourism and Sex Work in the Caribbean. Edited by Kamala Kempadoo. E-Book. Laham, Boulder, New York and Oxford: Littlefield Publishers.

Kinkaid, Jamaica. 1988. A Small Place. New York: Faraz, Strauz and Giroux.

Landes, Ruth. 1994. City of Women, 2nd ed. Albuquerque: University of New Mexico Press.

Mafeje, Archie. 2000. Africanity: A combative ontology. Codesria Bulletin 1: 66-71.

Martinez, Lourdes. 1998. Mestizaje and the discourse of national/cultural identity. Latin America Latin America Perspectives 25: 21-42.

Munanga, Kabenguele. 1999. Rediscutindo a Mestiçagem no Brasil: Identidade Nacional Versus Identidade Negra. Petrópolis: Vozes.

Nascimento, Elisa L. 2007. The Sorcery of Color: Identity, Race, and Gender in Brazil. Philadelphia: Temple University Press.

Nascimento, Beatriz, and Maria Teodoro Lopes. 1987. Negro e Cultura no Brasil. Rio de Janeiro: UNIBRADE Centro de Cultura.

Pinho, Osmundo. 1999. Espaço, poder e relações raciais: O caso do Centro Histórico de Salvador. Afro-Ásia, $257-74$. [CrossRef]

Pinho, Osmundo. 2010. O mundo Negro: Hermenêutica Crítica da Reafricanização em Salvador. Curitiba: Editora Progressiva.

Pravaz, Natasha. 2003. Brazilian mulatice: Performing race, gender, and the nation. Journal of Latin. American Anthropology 8: 116-47. [CrossRef]

Restrepo, Eduardo, and Arturo Escobar. 2005. Other anthropologies and anthropologies otherwise: Steps to a world anthropologies framework. In Critique of Anthropology. London, Thousand Oaks and New Delhi: Sage Publications, vol. 25, pp. 99-129.

Ribeiro, Darcy. 1995. O Povo Brasileiro: A formação e o sentido do Brasil. São Paulo: Companhia Das Letras.

Rocha, Luciane Oliveira. 2016. De-Matar: Maternidade negra como ação política na patria mãe (gentil?). In Antinegritude: O Impossível Sujeito Social na Formação Social Brasileira. Edited by Pinho Osmundo and Vargas João. Cruz das Almas and Belo Horizonte: UFRB and Fino Traço Editores, pp. 177-98.

Rodrigues, Nina. 2006. O Animismo Fetichista dos Negros Baianos. Edited by Maggie Yvonne and Fry Peter. Rio de Janeiro: Fundação Biblioteca Nacional e Editora daUFRJ.

Sansone, Lívio. 1998. Racismo sem etnicidade políticas públicas e discrminação racial em perspectiva comparada. Revista Dados 41: 751-84. [CrossRef]

Sansone, Lívio, and Osmundo Araújo Pinho. 2008. Raca; Novas Perspectivas Antropológicas. Salvador: Editora da UFBA.

Schwarcz, Lilia Moritz. 1993. O Espetáculo das Raças; Cientistas, Instituições e Questão Racial no Brasil 1870-1930. São Paulo: Companhia da Letras.

Skidmore, Thomas. 1990. The Idea of Race in Latin America. Austin: University of Texas Press.

Smith, Christen. 2016. Afro Paradise: Blackness, Violence and Performance in Brazil. Chicago: University of Illinois Press.

Soares, Maria Andrea S. 2015. Akoben: Performance, Politics, and Foundational Narratives of Blackness. Ph.D. dissertation, University of Texas Libraries, Austin, TX, USA.

Soares, Maria Andrea S. 2016. A Ontologia do Tema Negro: produção artística, autonomia e posicionalidade da negritude na mobilização do Akoben. In Antinegritude: o impossível sujeito negro na formação social brasileira (Pinho, Osmundo and Vargas, João, orgs). Belo Horizonte: UFRB print and Fino Traço print, pp. 217-35. 
Twine, France Winddance. 1998. Racism in a Racial Democracy: The Maintenance of White Supremacy in Brazil. New Brunswick: Rutgers University Press.

Velho, Otávio. 2008. A Antropologia e o Brasil, Hoje. Revista Brasileira de Ciências Sociais 23: 5-9. Available online: www.scielo.br/pdf/rbcsoc/v23n66/01.pdf (accessed on 22 December 2018). [CrossRef]

Vianna, Hermano. 1997. O Mundo Funk Carioca. Rio de Janeiro: Jorge Zahar Editora.

Vianna, Hermano. 2012. O Mistério do Samba: Música Popular e Identidade Nacional no Brasil, 2nd ed. Rio de Janeiro: Zahar Editor.

(C) 2019 by the author. Licensee MDPI, Basel, Switzerland. This article is an open access article distributed under the terms and conditions of the Creative Commons Attribution (CC BY) license (http://creativecommons.org/licenses/by/4.0/). 